\title{
Aplikasi SIG untuk Pemetaan Bahaya Kebakaran Hutan dan Lahan di Kota Dumai
}

\author{
Ria Viviyanti, Tamima Azri Adila, Riki Rahmad
}

Masuk: 28042019 / Diterima: 13122019 / Dipublikasi: 31122019

(c) 2019 Fakultas Hukum dan IImu Sosial UNDIKSHA dan IGI

\begin{abstract}
Forest and land fires occur by increasing the temperature and CO2 (Carbon Dioxide), an increase in temperature, which impacts the El Nino phenomenon in Indonesia, affecting the prolonged dry season so that it is vulnerable to forest and land fires. The objectives of this study were to describe the Dangers of Forest, and Land Fires in Dumai City based on forest and land fire parameters; and describe the use of GIS to map the Dangers of forest and land fires in Dumai City. The data used are Dumai City rainfall maps from 2008-2018 taken from two station points, maps of Dumai City soil type, and land use maps of Dumai City made from Landsat 8 images and inputted with ArcGIS 10.4 software. Overall, in Dumai City, the kind of land is open land (upland, bush) with an area of 170648753 or $75.08 \%$, then forest with an area of 43606288 or $19.19 \%$, and gardens/plantations with an area of 13024469 or $5.73 \%$. The level of forest and land fire hazards that occur in Dumai City with class scores used that there is $19.20 \%$ of the area in Dumai City is included in the class while the danger of forest and land fires. At the same time, there is $80.20 \%$ of the area covered in the high level of fire hazards forest and land.
\end{abstract}

Key words: Geographic Information System; Mapping; Forest and Land Fires

\begin{abstract}
Abstrak Kebakaran hutan dan lahan terjadi oleh peningkatakan suhu dan Karbon Dioksida, peningkatan suhu dipengaruhi oleh fenomena EL Nino di Indonesia berdampak terhadap musim kemarau yang berkepanjangan sehingga rentan terhadap terjadinya kebakaran hutan dan lahan. Tujuan dari penelitian ini adalah mendeskripsikan Bahaya Kebakaran Hutan dan Lahan di Kota Dumai berdasarkan parameter-parameter kebakaran hutan dan lahan; dan mendeskripsikan Pemanfaatan penggunaan SIG untuk melakukan pemetaan tentang bahaya kebakaran hutan dan lahan di Kota Dumai. Data yang digunakan yaitu peta curah hujan Kota Dumai dari tahun 2008-2018 yang diambil dari dua titik stasiun, peta jenis tanah Kota Dumai, dan peta penggunaan lahan Kota Dumai yang diambil dari citra landsat 8 , dan di input dengan sofwere ArcGIS 10.4. Secara keseluruhan di Kota Dumai jenis lahan yaitu lahan terbuka (Tegalan, semak) dengan luas 170648753 atau $75,08 \%$, kemudian hutan dengan luas 43606288 atau 19,19\%, dan kebun/perkebunan dengan luas 13024469 atau $5,73 \%$. Tingkat bahaya kebakaran hutan dan lahan yang terjadi di Kota Dumai dengan skor kelas yang digunakan bahwa terdapat $19,20 \%$ wilayah di Kota Dumai termasuk kedalam kelas sedang bahaya kebakaran hutan dan lahan, sementara terdapat $80,20 \%$ luas wilayahnya termasuk kedalam kelas tinggi bahaya kebakaran hutan dan lahan.
\end{abstract}

Kata kunci : Sistem Informasi Geografis; Pemetaan; Kebakaran Hutan dan Lahan

\section{Pendahuluan}

Kebakaran hutan adalah bencana yang terjadi di areal hutan dan lahan yang memiliki titik api. Kebakaran hutan merupakan permasalahan bencana yang terjadi di Indonesia, bahkan hampir setiap tahunnya ketika musim kemarau tiba.

Ria Viviyanti, Tamima Azri Adila, Riki Rahmad Jurusan Pendidikan Geografi, FIS,

Universitas Negeri Medan

rikirahmad@unimed.ac.id
Kebakaran hutan dan lahan masih jadi perdebatan, sebab banyak faktor-faktor yang disebabkan karena faktor non alamiah, dan faktor alamiah. Kebakaran hutan yang terjadi banyak menimbulkan kerugian baik secara ekonomis maupun non ekonomis. Seperti yang sudah diketahui banyak wilayah di Indonesia yang masih memiliki kerentanan terhadap bahaya kebakaran. Kerentanan awal mulanya sering digunakan dalam berbagai 
literatur untuk menjelaskan adanya risiko, bahaya dan bencana, tetapi menjadi lebih menonjol di bidang perubahan iklim global dan studi lingkungan hingga pembangunan (Cutter, 1996). Kerentanan merupakan keterbatasan dalam merespon situasi karena kemungkinan masalah kesehatan, keterbatasan dukungan ekonomi, kurangnya akses ke sumber daya penting selama peristiwa bencana hingga respon untuk memulihkan diri dari situasi bencana (Garbutta, Ellulb, \& Fujiyamab, 2015). BAKORNAS PB mendefenisikan kerentanan sebagai sekumpulan kondisi dan atau suatu akibat faktor fisik, sosial, ekonomi dan lingkungan yang berpengaruh buruk terhadap upaya-upaya pencegahan dan penanggulangan bencana (Hapsoro \& Buchori, 2015). Mengingat masih banyaknya daerah yang rentan terhadap kebakaran lahan dan hutan maka perlu mendapat perhatian serius.

Kebakaran hutan yang sudah terjadi pada tahun 1982, terus berlanjut disetiap tahunnya ketika memasuki musim kemarau (Asterindah, 2017). Kebakaran hutan yang terjadi pada tahun 2015 Indonesia memberikan dampak kabut asap hingga ke negara tetangga Singapura, dan Malaysia.

Menurut (Wesnawa \& Christiawan, 2014) kebakaran hutan adalah penyebaran bahan organik yang bebas di hutan akibat proses pembakaran, kebakaran hutan mengkonsumsi bahan bakarnya berupa alam hutan yaitu gambut, seresah, ranting-ranting, gulam, semak, serta pohon-pohon segar. Kebakaran hutan dan lahan yang terjadi merupakan salah satu faktor hutan rusak serta menimbulkan dampak terhadap kondisi flora dan fauna yang ada di dalamnya. Dampak kebakaran hutan lebih besar lagi terhadap sistem hidrologi, degradasi lahan, banjir dan erosi tanah, serta hilangnya keanekaragaman hayati, hingga degradasi hutan dan lahan (Ajin, Loghin, Vinod, \& Jacob, 2016).
Indonesia sering terjadi bencana kebakaran hutan dan lahan. Kebakaran hutan dan lahan diakibatkan mulai dari peningkatan $\mathrm{CO}_{2}$ (Karbon Dioksida) dan suhu. Peningkatan suhu diakibatkan oleh fenomena EL Nino yang telah terjadi sehingga menimbulkan dampak yang lebih besar terhadap lahan kering ataupun kondisi pemicu kebaran hutan di Indonesia. Perubahan iklim global yang terjadi berdampak terhadap musim kemarau yang berkepanjangan sehingga rentan terhadap terjadinya kebakaran hutan dan lahan.

Fenomena EL Nino dan perubahan iklim global bukanlah faktor utama pemicu terjadinya kebarakan hutan dan lahan di Indonesia, namun adanya faktor lain (non alamiah) yang menyebabkan kebarakan hutan dan lahan. Pembukaan lahan sawit dengan membakar hutan merupakan pemicu kebarakan hutan dan lahan yang terjadi di Indonesia. Hal tersebut juga senada yang disampaikan oleh Ketua BNPB Sutopo Purwo Nugroho menyebutkan bahwa 99,9\% penyebab kebaran hutan dan lahan adalah sengaja dibakar untuk pembersihan lahan dan perluasan perkebunan kelapa sawit.

Kebakaran hutan dan lahan juga dapat dipenagruhi oleh kondisi biofisiknya, kebakaran hutan dan lahan yang terjadi di Indonesia sebagian besar terjadi di lahan gambut selama 10 tahun terakhir. Kebakaran hutan dan lahan di Indonesia sudah terjadi semenjak tahun 1982/1983, 1991, 1994, 1998, 1998, 2013, 2015, meskipun hampir setiap tahunnya beberapa wilayah di Indonesia sering terjadi kebakaran hutan dan lahan, dan diperkirakan pada tahun 1997/1998 kebakaran hutan payau dan gambut mencapai 2.124.000 hektar.

Pembukaan lahan yang terjadi pada lahan gambut mengakibatkan penurunan air yang memiliki bahaya kebakaran hutan dan lahan. Kebakaran hutan dan lahan tidak hanya terjadi pada 
lahan yang kering, namun lahan yang basah seperti lahan gambut. Lahan gambut memiliki bahaya kebakaran sebab ketika musim kemarau tiba, terjadi penurunan kandungan air (Rauf, 2016).

Luas lahan gambut Indonesia diperkirakan mencapai 20,6 juta hektar, $10,8 \%$ dari luas daratan Indonesia. Persebaran lahan gambut banyak terdapat di Sumatra dan Kalimantan, tercata 7,2 hektar atau sekitar 35\% terdapat di Sumatra dan 5,67 hektar atau 27,8\% terdapat di wilayah Kalimantan.

Riau memiliki lahan gambut seluas $50 \%$ dari 8,7 juta hektar hutan, dan merupakan lahan gambut terluas yang ada di Sumatra. Wilayah Riau hampir keseluruhan sering terjadi kebakaran hutan dan lahan. Kebakaran hutan dan lahan di Riau terjadi dari Januari hingga April, menurut Badan Penangulangan Bencana Daerah (BPBD) Riau, mencatat 1.647,36 ha terbakar. Terdapat 12 kabupaten yang ada di Riau 11 kabupaten diantaranya terjadi kebakaran hutan, yaitu Rokan Hulu 1 ha, Rokan Hilir 80.75 ha, Dumai 114.25 ha, Bengkalis 160.5 ha, Kepulauan Meranti 896.61 ha, Siak 131.5 ha, Pekanbaru 31 ha, Kampar 19.25 ha, Pelalawan 60 ha, Indragiri Hilir 121.5 ha, dan Indragiri Hulu 31 ha.

Dumai adalah salah satu dari 12 kabupaten yang ada di Riau, dan 11 kabupaten terjadi kebakaran hutan. Kebaran hutan dan lahan setiap tahunnya sering terjadi di Dumai. Terdapat dua kecamatan yang memiliki bahay terhadap kebakaran hutan dan lahan yaitu Kecamatan Sungai Sembilan, dan Kecamatan Medang Kampai (BPS Dumai, 2018).

Saat kondisi alami tanah gambut mampu menahan dan menyerap air, akan tetapi jika sudah memasuki musim kemarau tanah gambut akan mengalami penurunan kandungan air sehingga terjadi kekeringan samapai kedalaman tertentu sehingga mudah terbakar. Tanah gambut yang sudah mengalami gangguan akan dapat mengganggu keseimbangan ekologisnya (Saputra, Sigit, \& Shandyavitri, 2017).

Banyak parameter yang digunakan untuk melakukan pemetaan mengenai bahaya kebakaran hutan dan lahan. (Putra, Retnaningsih, \& Ikhwan, 2018) mengunakan lima parameter yaitu, penggunaan lahan, jenis tanah, curah hujan, ketinggian tempat, dan jarak permukiman. Analisis kebakaran hutan dan lahan dengan memanfaatkan teknologi penginderaan jauh dan system informasi geografis masih tergolong baru dan belum banyak dilakukan. Padahal sesuai dengan perkembangan teknologi pemetaan penginderaan jauh dan system informasi geografis memberikan suatu kemudahan dan keakurasian dalam menyajikan informasi geospasial untuk bidang kebencanaan khususnya kebakaran. Pemodelan spasial dengan mempertimbangkan parameter curah hujan, jenis tanah dan penggunaan lahan untuk mengetahui ancaman bahaya kebakaran menjadi suatu penelitian yang sangat penting dilakukan mengingat kebermanfaatannya untuk masyarakat secara luas. Oleh karena itu, judul penelitian yang diangkat adalah "Aplikasi SIG untuk Pemetaan Bahaya Kebakaran Hutan dan Lahan di Kota Dumai". Tujuan dari penelitian ini adalah (1) mendeskripsikan Bahaya Kebakaran Kebakaran Hutan dan Lahan di Kota Dumai berdasarkan parameter-parameter kebakaran hutan dan lahan; (2) Mendeskripsikan Pemanfaatan Penggunaan SIG untuk melakukan pemetaan tentang Bahaya kebakaran hutan dan lahan di Kota Dumai. SIG merupakan sebuah sistem yang didesain untuk menangkap, menyimpan, memanipulasi, menganalisa, mengatur, dan menampilkan seluruh jenis dan tipe data geografi (Rahayu, Mulud, \& Hijriani, 2016). 


\section{Metode}

Lokasi penelitian pemetaan ini adalah wilayah yang memiliki bahaya terhadap kebakaran hutan dan lahan di Riau yang berlokasi di Kota Dumai. Pemanfaatan SIG untuk melakukan pemetaan bahaya kebakaran hutan dan lahan di Kota Dumai menggunakan beberapa data. Data yang digunakan yaitu peta curah hujan kota dumai dari tahun 2008-2018 yang diambil dari dua titik stasiun, peta jenis tanah Kota Dumai, dan peta penggunaan lahan Kota Dumai yang diambil dari citra landsat 8 .

Data berupa peta curah hujan, peta jenis tanah, dan peta penggunaan lahan di input dengan sofwere ArcGIS 10.4. Data keluaran yang didapat kemudian dijadikan acuan untuk wilayah penelitian serta acuan analisis menegnai bahaya kebakaran hutan dan lahan di Kota Dumai. Peta curah hujan, peta jenis tanah, peta penggunaan lahan yang yang sudah siap dalam peta digital kemudian dianalisis untuk mengetahui bahaya kebaran hutan dan lahan di Kota Dumai. Peta yang sudah bentuk digital kemudian di klasifikasikan berdasarkan skoring yang ada dan kemudian diberi bobot untuk masing-masing parameter tentang bahaya kebakaran hutan dan lahan kemudian dianalisis.

Dalam mengnalisis bahaya kebakaran hutan dan lahan menggunakan model parameter yang mengacu kepada buku Risiko Bencana Indonesia oleh BNPB dengan formula:

\section{Skor Total $=0,4 \mathrm{PJL}+0,3 \mathrm{PCH}+0,3$ PJT}

Keterangan:

$\begin{array}{ll}\mathrm{PJL} & =\text { Parameter Jenis Lahan } \\ \mathrm{PCH} & =\text { Parameter Curah Hujan } \\ \mathrm{PJT} & =\text { Parameter Jenis Tanah } \\ 0,4+0,3+0,3= & \text { Bobot Nilai }\end{array}$

Tabel. 1 Klasifikasi Jenis Lahan

\begin{tabular}{|c|c|c|}
\hline Parameter & Bobot & Skor \\
\hline Hutan & & 0,333 \\
\hline Kebun/Perkebunan & $40 \%$ & 0,666 \\
\hline Tegalan/Lahan Terbuka & & 1 \\
\hline
\end{tabular}

Sumber : Risiko Bencana Indonesia (BNPB, 2013)

Tabel. 2 Klasifikasi Curah Hujan (mm/tahun)

\begin{tabular}{lccc}
\hline & Parameter & Bobot & Skor \\
\hline$>3000 \mathrm{~mm}$ & & 0,333 \\
$1500-3000 \mathrm{~mm}$ & $30 \%$ & 0,666 \\
$<15000$ & & 1 \\
\hline
\end{tabular}

Sumber : Risiko Bencana Indonesia (BNPB, 2013)

Tabel. 3 Klasifikasi Jenis Tanah

\begin{tabular}{lccc}
\hline & Parameter & Bobot & Skor \\
\hline Non Organik & & $30 \%$ & 0,333 \\
- & & 0,666 \\
Organik/Gambut & & 1 \\
\hline
\end{tabular}

Sumber : Risiko Bencana Indonesia (BNPB, 2013)

\section{Hasil dan Pembahasan}

Secara geografis Kota Dumai terletak pada posisi $1^{\circ} 23^{\prime} 00^{\prime \prime}-1^{\circ} 24^{\prime} 23^{\prime \prime}$ Lintang Utara dan $101^{\circ} 23^{\prime} 37^{\prime \prime}-101^{\circ} 28^{\prime} 13^{\prime \prime}$ Bujur
Timur. Luas Kota Dumai adalah 1,727.38 $\mathrm{Km}^{2}$ dengan batas-batas wilayah sebagai berikut. Sebelah Utara berbatasan dengan Selat Rupat. Sebelah Timur berbatasan 
dengan Kecamatan Bandar Laksamana Kabupaten Bengkalis. Sebelah Selatan berbatasan dengan Kecamatan Bathin Solapan dan Kecamatan Bukit Batu Kabupaten Bengkalis. Sebelah Barat berbatasan dengan Kecamatan Tanah Putih dan Kecamatan Sinaboi Kabupaten Rokan Hilir.

Wilayah Kota Dumai sebagian terdiri dari disebalah Utara merupakan dataran rendah dan sebelah Selatan merupakan dataran tinggi.

\section{Parameter-Parameter Tentang Bahaya Kebakaran Hutan dan Lahan Kota Dumai}

\section{Penggunaan Lahan}

Berdasarkan hasil interpretasi citra landsat 8 Kota Dumai tahun 2018, diperoleh tiga tipe penggunaan lahan yaitu, lahan terbuka (tegalan, semak), hutan, dan perkebunan. Untuk lebih jelas mengenai penggunaan lahan yang ada di Kota Dumai seperti terlihat pada Gambar 1.

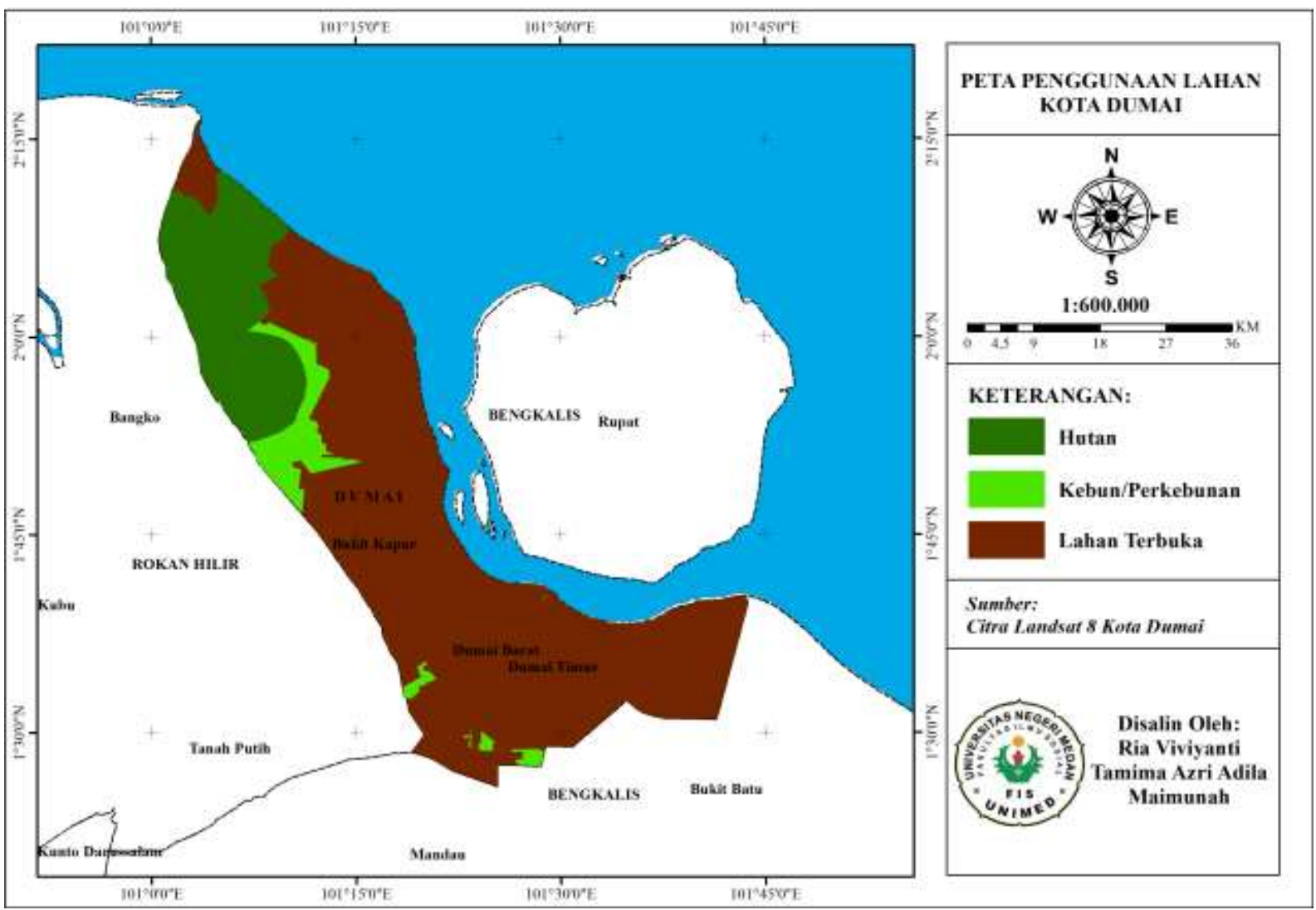

. Gambar 1. Peta Penggunaan Lahan Kota Dumai

Tabel. 4 Penggunaan Lahan Kota Dumai Tahun 2018

\begin{tabular}{|c|c|c|}
\hline Jenis Lahan & Luas $(\mathrm{Ha})$ & Persentae \\
\hline Lahan Terbuka & 170648753 & $75,08 \%$ \\
\hline Kebun/Perkebunan & 130214469 & $5,73 \%$ \\
\hline Hutan & 43606288 & $19,19 \%$ \\
\hline Jumlah & 227276481 & $100 \%$ \\
\hline
\end{tabular}

Sumber: Pengolahan Data Primer (2018)

Jenis lahan terbuka memiliki bahaya kebakaran hutan yang tinggi, berdasarkan parameter yang digunakan oleh BNPB bahwa lahan terbuka memiliki skor 1 yang merupakan skor tertinggi untuk parameter bahaya kebakaran hutan 
dan lahan. Lahan terbuka (tegalan, semak), memiliki tingkat kepekaan bahaya kebakaran hutan yang tinggi karena pada jenis lahan ini banyak mengandung bahan bakar kering dan memiliki tingkat kelembapan rendah.

Berdasarkan dari Gambar 4, serta Tabel 4 maka diperoleh hasil bahwa secara keseluruhan di Kota Dumai jenis lahan yaitu lahan terbuka (Tegalan, semak), kemudian hutan, dan kebun/perkebunan. Luas wilayah dari jenis lahan di Kota Dumai yaitu jenis lahan terbuka memiliki luas 170648753 75,08\%, luas hutan 43606288 atau $19,19 \%$ dan kebun/perkebunan yaitu 13024469 atau $5,73 \%$. Hal tersebut sesuai dengan hasil penelitian yang dilakukan oleh Jawad, Nurdjali, \& Widiastuti (2015), berdasarkan analisis spasial terhadap penutupan lahan, ternyata penutupan lahan/vegetasi Belukar, Sawah dan Pertanian Lahan Kering Sekunder merupakan vegetasi yang paling peka terhadap bahaya kebakaran dibanding jenis penutupan lahan lainnya, hal ini karena jenis penutupan lahan tersebut mengandung banyak bahan bakar ringan dan umumnya relatif kering karena kelembaban lingkungannya rendah.

Hal tersebut juga sejalan dengan penelitian yang dilakukan oleh Tata, Narendra, \& Nawazin (2017), bahwa pada tanah terbuka, belukar rawa dan pertanian kering campur memiliki banyak titik api.

Selain itu kebiasaan masyarakat Kabupaten Musi Banyuasin yang membakar vegetasi (rasau, pandan) dengan cara dibakar. Penelitian sejenis juga pernah dilakukan oleh Mapilata, Gandasasmita, \& Djajakirana, (2013) mengkaji tentang zonasi kerentanan kebakaran lahan dan hutan di Kecamatan Malifut yang mengemukakan bahwa sebaran kerentanan kebakaran yang sangat luas mulai dari kelas sedang hingga tinggi pada masing-masing jenis tutupan lahan merupakan dampak dari kondisi perubahan penggunaan atau alih fungsi lahan. Lahan yang kecenderungan dijadikan kawasan pertanian dan perkebunan atau kawasan produksi secara langsung mendorong indeks kerentanan kebakaran semakin tinggi. Sedangkan menurut Jawad et al. (2015) mengemukakan bahwa terjadi perubahan penutupan lahan dari vegetasi yang sulit terbakar menjadi vegetasi yang lebih peka atau mudah terbakar yang disebabkan oleh pembukaan areal perkebunan dan aktivitas manusia. Perubahan jenis tutupan lahan secara nyata mengambil bagian penting dalam mengontrol indeks kerentanan kebakaran lahan dan hutan satu kawasan (Christiawan, 2018). Sehingga perubahan jenis tutupan lahan yang cenderung lebih dinamis dari suatu sistem lahan dapat menentukan tingkat kerentanan kebakaran lahan tersebut.

\section{Curah Hujan}

Berdasarkan data dari Stasiun BMKG Riau terkait dengan curah hujan di Kota Dumai, maka curah hujan berkisar antara 2,118-2,876. Data mm/tahun. Untuk lebih jelas maka dapat dilihat peta curah hujan Kota Dumai pada Tabel 5 dan Gambar 2.

Tabel. 5 Curah Hujan Kota Dumai Tahun 2018

\begin{tabular}{lccc}
\hline & Curah Hujan & Luas (Ha) & Persentase \\
\hline$<2600$ & 319691217 & $14,07 \%$ \\
$2600-2650$ & 272766459 & $12,01 \%$ \\
$2700-2750$ & & 545365915,9 & $24,00 \%$ \\
$>2800$ & 1134215857 & $49,92 \%$ \\
\hline
\end{tabular}

Sumber: Pengolahan Data Tahun 2018 


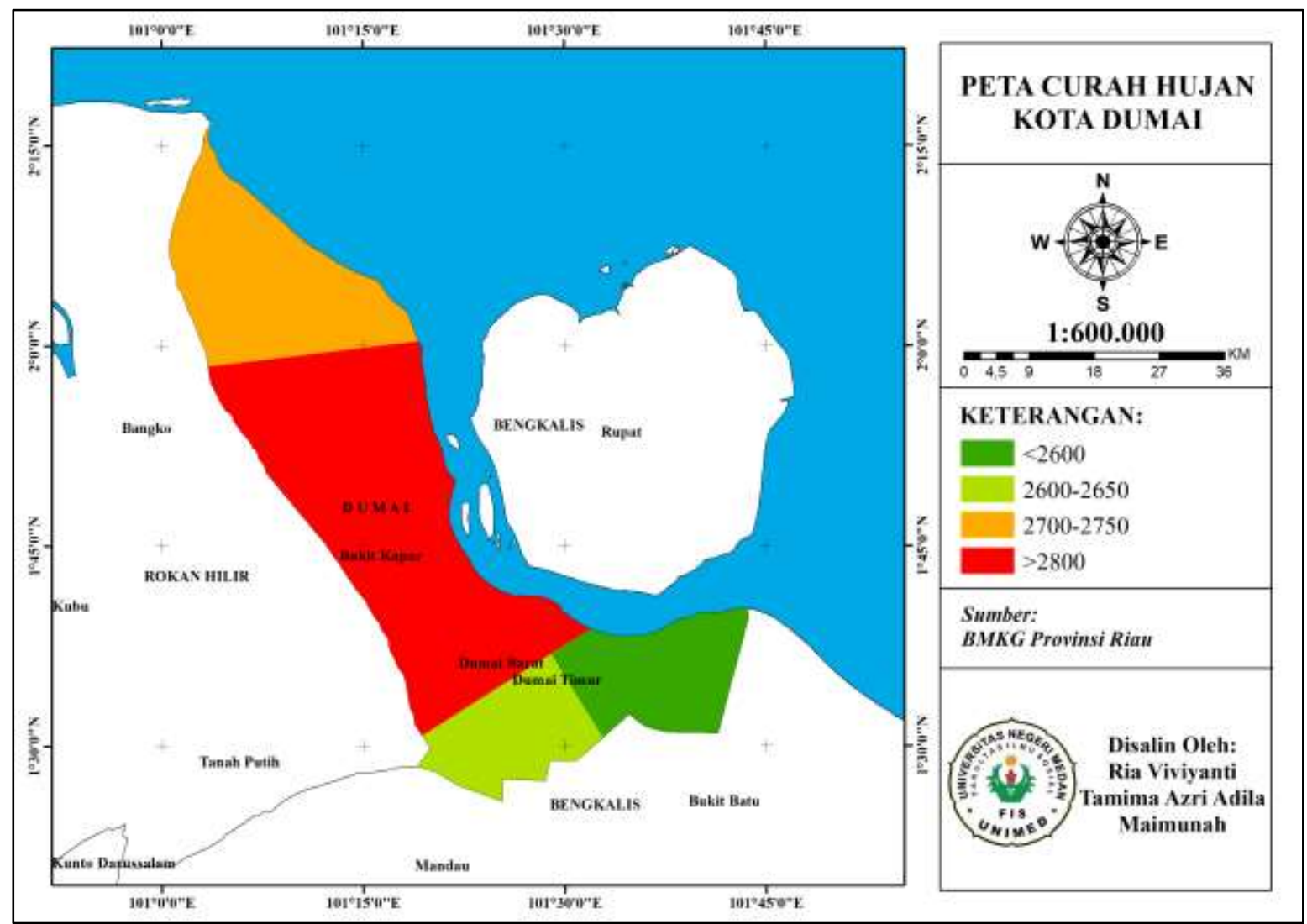

Gambar 2. Peta Curah Hujan Kota Dumai

Kebakaran hutan dan lahan terjadi pada musim kemarau. Berdasarkan gambar peta curah hujan Kota Dumai sekitar diatas 2,800. Berdasarkan parameter oleh BNPB bahwa untuk curah hujan di Kota Dumai termasuk kedalam kategori 2 sebesar $(0,666)$. Curah hujan $>2800$ memiliki luasan wilayah yang paling luas yang ada di Kota Dumai. Berdasarkan tabel 5 luas wilayah di Kota Dumai yang memiliki curah hujan (mm/tahun) $<2600$ memiliki luas wilayah 31961217 atau $14,07 \%$, curah hujan $2.600-2650$ memiliki luas wilayah 272766459 atau 12,01 \%, 2700-2750 memiliki luas wilayah 54536591519 atau $24,00 \%$ dan curah hujan > 2800 memiliki luas wilayah 1134215857 atau 49,92\%. Keaadan iklim dan cuaca berpengaruh terhadap bahaya kebakaran hutan dan lahan, sebab wilayah yang kering akan sensitf untuk terbakar. Penelitian yang dilakukan oleh Tata et al. (2017), pada saat curah hujan terendah banyak terjadi kebakaran hutan dan lahan, karena bahan bakar potensial lebih cepat terbakar pada saat musim hujan rendah. Menurut (Wesnawa \& Christiawan, 2014) menyatakan bahwa penyebab kebakaran hutan dan lahan di Indonesia disebabkan oleh konversi hutan yang sudah tidak terkendali, selain itu iklim yang ekstrim juga menjadi pemicu kebakaran hutan dan lahan yang terjadi di Indonesia. Hasil penelitian yang didapat oleh Widodo (2014) yang mengemukakan bahwa korelasi antara data curah hujan dengan titik panas perlu dilakukan pemantauan untuk dilakukan deteksi dini kejadian kebakaran hutan dan lahan, karena data curah hujan dapat digunakan sebagai salah satu faktor kerentanan suatu daerah untuk terjadi kebakaran hutan.

\section{Jenis Tanah}

Berdasarkan data yang didapat bahwa hampir secara keseluruhan wilayah di Kota Dumai memiliki jenis tanah 
organik/gambut, kemudian terdapat tanah non-organik/sedimen namun tidak terlalu banyak. Untuk lebih jelas mengenai jenis tanah Kota Dumai dapat dilihat pada Gambar 4.

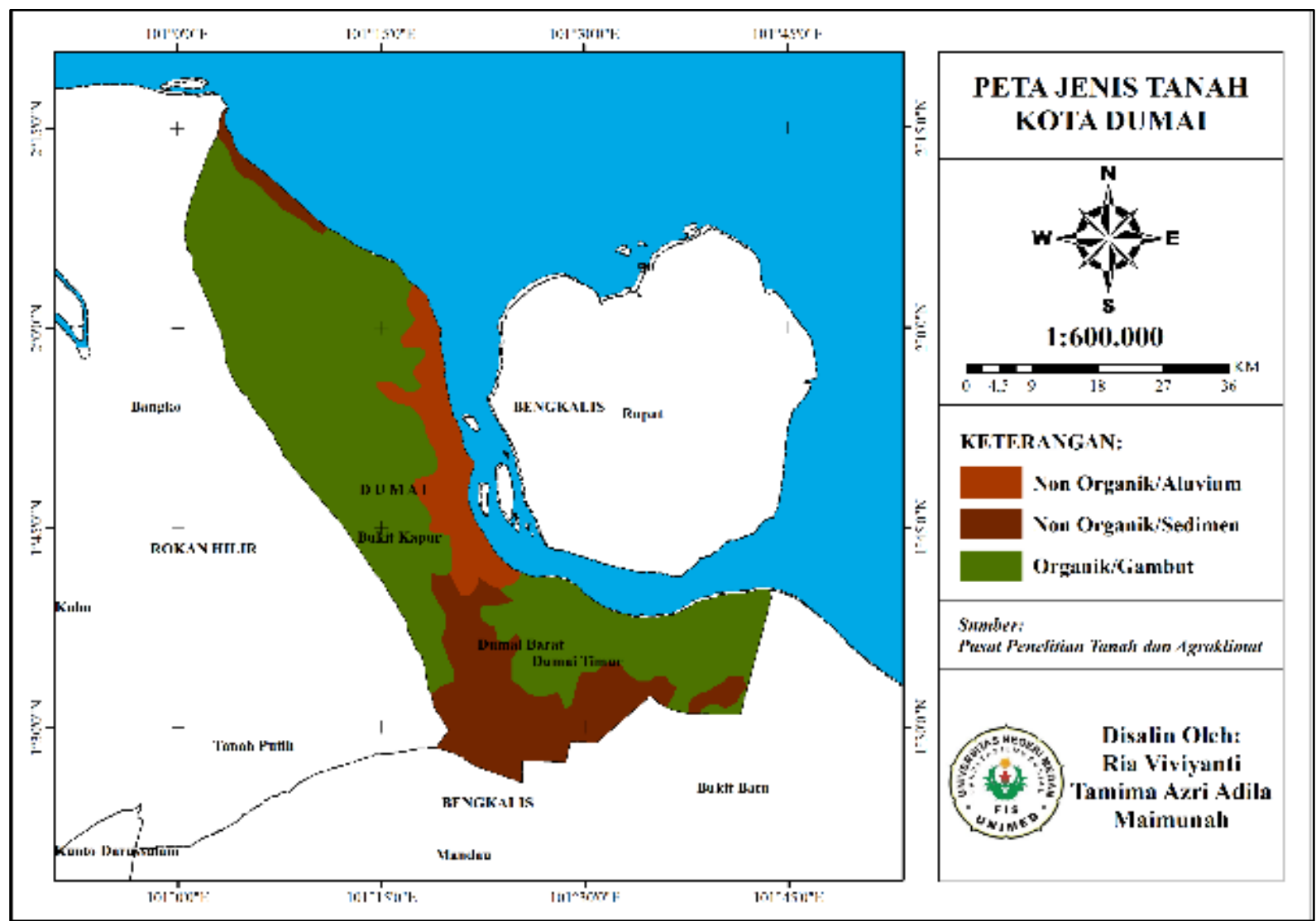

Gambar. 4 Peta Jenis Tanah Kota Dumai

Tabel. 6 Jenis Tanah Kota Dumai

\begin{tabular}{|c|c|c|}
\hline Jenis Tanah & Luas (Ha) & Persentase \\
\hline Non Organik /Sedimen & 221923931,7 & $9,77 \%$ \\
\hline Non Organik/Aluvial & 444518282,7 & $19,56 \%$ \\
\hline Organik/Gambut & 1605602547 & $70,67 \%$ \\
\hline Jumlah & 2272044761 & $100 \%$ \\
\hline
\end{tabular}

Sumber: Pengolahan Data Tahun 2018

Berdasarkan Gambar 4 terlihat bahwa hampir secara keseuruh wilayah di Kota Dumai bertanah organik/gambut. Berdasarkan parameter yang digunakan dari BNPB bahwa untuk tanah organik berskor 1 dan tanah non organik memiliki skor 0,333. Tanah jenis organik/gambut memiliki tingkat yang tinggi terhadap bahaya kebakaran hutan dan lahan sebab, tanah organik/gambut terdiri dari rantingranting pohon, sersah, sisa tanaman, serta akumulasi tumbuhan yang setengah membusuk. Berdasarkan data tabel 6 luas wilayah jenis tanah di Kota Dumai yaitu, tanah non organik/sedimen seluas $221923931,7 \mathrm{~m}^{2}$ atau $9,77 \%$, tanah non organik/Aluvial memiliki luas 444518282,7 atau $19,56 \%$, sementara jenis tanah oranik/gambut memiliki luas 1605602547 atau $70,76 \%$ dari total keseluruhan jenis tanah yang ada di Kota Dumai. Tanah organik memiliki persentase paling besar 
untuk wilayah Kota Dumai. Meskipun tanah ini bersifat lembab, namun ketika musim kemarau tanah ini mengalami penurunan tingkat kelembapan sehingga sangat peka terhadap kebakaran hutan dan lahan, selain itu terdapat bahan bakar alami yang terdapat didalam kandungan tanah organik/gambut.

Hasil penelitian yang dilakukan oleh Lembaga Penelitian dan Pengabdian Kepada Masyrakat CROMM SEP, Bogor Agriculture Institute (2016) bahwa Lahan gambut sangat dangkal menjadi area yang aktivitas kebakarannya tertinggi diduga karena areal tersebut semakin luas dibuka untuk lahan pertanian dan perkebunan. Pembukaan lahan untuk lahan pertanian dan perkebunan umumnya menggunakan api dalam proses pembersihan lahan. Hasil penelitian yang dilakukan oleh Ratnaningsih \& Prastyaningsih (2017) apabila terjadi kebakaran lahan gambut memiliki kemungkinan besar merambat ke dalam lapisan gambut maka semakin turun dalam titik permukaan air maka semakin kering tanah gambut yang mudah terbakar.

\section{Aplikasi SIG Dalam Pemetaan Bahaya Kebakaran Hutan dan Lahan Di Kota Dumai}

Pemetaan bahaya kebakaran hutan dan lahan di Kot Medan dengan menggunakan model parameter Rissiko Bencana Indonesia oleh BNPB. Parameter yang digunakan yaitu Penggunaan Lahan,
Curah Hujan, dan Jenis Tanah. Parameter yang digunakan kemudian diklasifikasikan menurut skor yang kemudian diberi bobot untuk masing-masing parameter dan kemudian data tersebut di olah dan dianalisis. Hasil analisi dari parameter yang digunakan tentang bahaya kebakaran hutan dan lahan dengan menggunakan model pendugaan dari Risiko Bencana Indonesia Oleh BNPB, didapat 3 kriteria bahaya kebakaran hutan dan lahan yaitu, Rendah, Sedang, dan Tinggi. Dengan pendugaan dari Risiko Bencana Indonesia oleh BNPB mendapat bobot $40 \%$ untuk penggunaan lahan, 30\% untuk curah hujan, dan $30 \%$ untuk jenis tanah. Untuk menganalisis bahaya kebakaran hutan dan lahan maka digunakan model sebagai berikut.

\section{Skor Total $=0,4 \mathrm{PJL}+0,3 \mathrm{PCH}+0,3$ PJT}

$$
\begin{aligned}
& \text { Keterangan: } \\
& \begin{array}{ll}
\text { PJL } & =\text { Parameter Jenis Lahan } \\
\text { PCH } & =\text { Parameter Curah Hujan } \\
\text { PJT } & =\text { Parameter Jenis Tanah } \\
0,4+0,3+0,3 & =\text { Bobot Nilai }
\end{array}
\end{aligned}
$$

Berdasarkan analisis parameter dan bobot yang digunakan, maka diperoleh klasifikasi bahaya kebakaran hutan dan lahan dengan kelas Rendah, Sedang, dan

\begin{tabular}{|c|c|}
\hline Interval Skor (\%) & Kelas Bahaya \\
\hline $0-0,333$ & Rendah \\
\hline $0,334-0,666$ & Sedang \\
\hline $0,667-1$ & Tinggi \\
\hline
\end{tabular}
Tinggi. Untuk lebih jelasnya dapat dilihat pada Tabel 7.

Tabel 7 Interval Skor Kelas Tingkat Bahaya Kebakaran Hutan dan Lahan di Kota Dumai

Sumber: Pengolahan Data Tahun 2018 


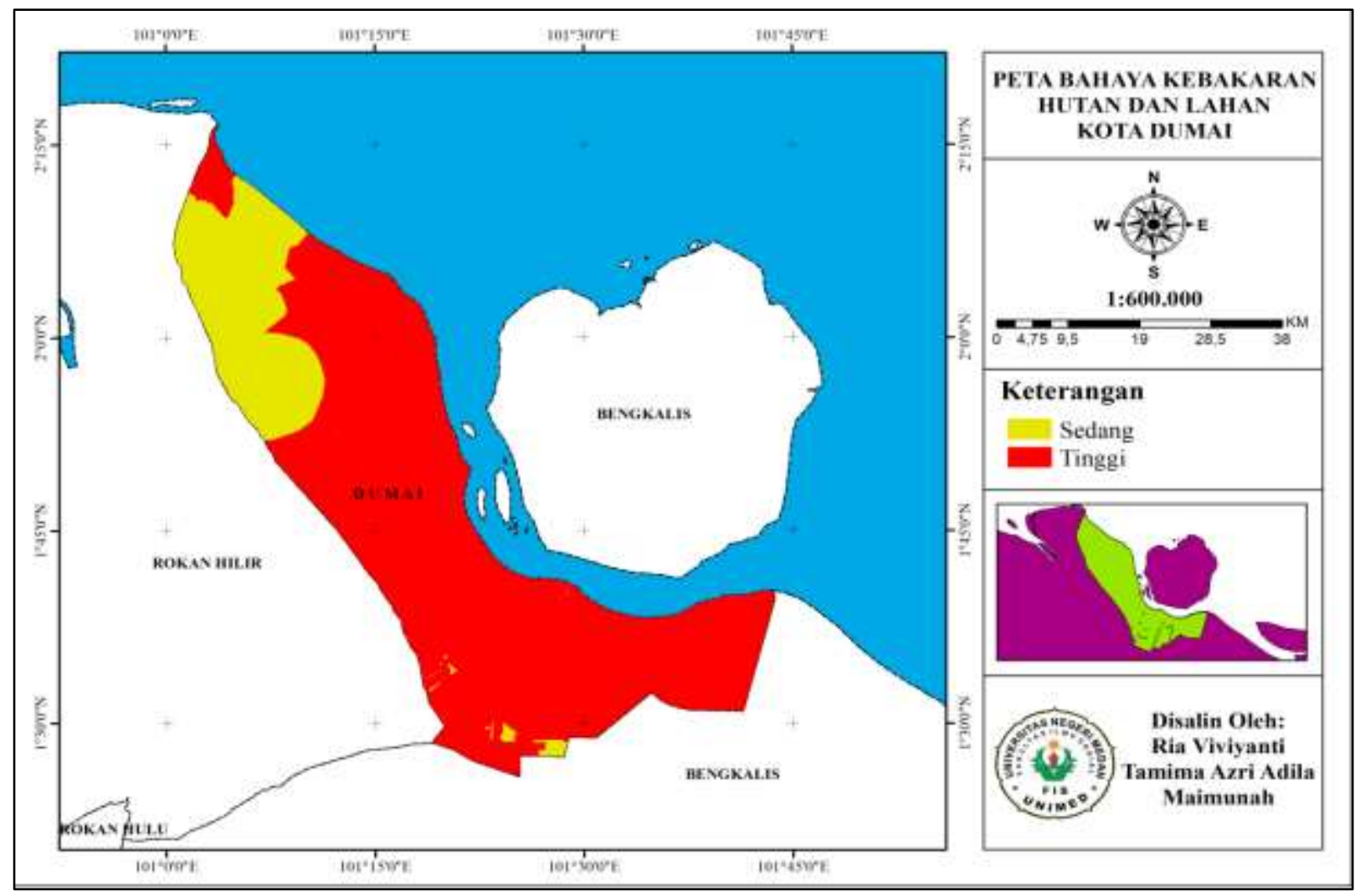

Gambar 5. Peta Bahaya Kebakaran Hutan dan Lahan di Kota Dumai

Tabel 8. Luas Wilayah serta Persentase Bahaya Kebakaran Hutan dan Lahan di Kota Dumai

\begin{tabular}{lrr}
\hline Parameter & Luas(Ha) & Persentase \\
\hline Sedang & 449,146058 & $19,80 \%$ \\
Tinggi & 1819,117643 & $80,20 \%$ \\
\hline Total & 2268,263701 & $100,00 \%$ \\
\hline
\end{tabular}

Sumber: Pengolahan Data Tahun 2018

Analisis hasi overlay diperoleh 2 kelas untuk Kota Dumai (Gambar 5) yaitu sedang dan tinggi. Selain itu, kategori tinggi merupakan daerah yang terbesar yang dimiliki oleh Kota Dumai (Tabel 8) sehingga dikatakan memiliki potensi kebakaran hutan tinggi. Berdasarkan hasil analisis, diperoleh tingkat bahaya kebakaran hutan dan lahan yang terjadi di Kota Dumai dengan skor kelas yang digunakan bahwa terdapat $19,20 \%$ wilayah di Kota Dumai termasuk kedalam kelas sedang bahaya kebakaran hutan dan lahan, sementara terdapat $80,20 \%$ luas wilayahnya termasuk kedalam kelas tinggi bahaya kebakaran hutan dan lahan.

\section{Kesimpulan}

Hasil pengolahan membuktikan bahwa tiga parameter yang diguankan untuk mengetahui bahaya kebakaran hutan dan lahan di Kota Dumai, yaitu penggunaan lahan, curah hujan, dan peta jenis tanah. Penggunaan lahan di Kota Dumai yiatu lahan terbuka (tagelan, semak), kebun/perkebunan dan hutan. Curah hujan di Kota Dumai termasuk kedalam kategori sedang yaitu 2118-2876 $\mathrm{mm} /$ tahun. (3) Kota Dumai memiliki jenis tanah yaitu tanah organic/gambut, tanah non organik/sedimen, semntara itu jenis tanah yang paling dominan di Kota Dumai adalah jenis tanah organic/gambut. Permodelan SIG yang diguankan bermanfaat untuk mengetahui bahaya 
kebakaran hutan dan lahan di Kota Dumai. Permodelan SIG dilakukan dengan menggunakan pendugaaan parameter bahaya kebakaran hutan dan lahan di Kota Dumai dengan perolehan tingkat bahaya dari sedang-tinggi, untuk wilayah di Kota Dumai lebih dominan dengan bahaya kabakaran hutan dan lahan dalam kelas tinggi. Penelitian terkait kebakaran lahan dan hutan dengan memanfaatkan teknologi penginderaan jauh dan sistem informasi geografis dapat diterapkan juga di daerah lain namun harus tetap memperhatikan pertimbangan penentuan parameter yang berpengaruh sesuai karakteristik daerah penelitian.

Saran yang dapat disampaikan adalah perlu pengembangan suatu teknik pemodelan spasial yang lebih detail lagi dalam menganalisis bahaya kebakaran, pertimbangan terkait kebutuhan data spasial yang lebih akurat juga perlu diperhatikan dalam penelitian ini hanya menggunakan data Citra Landsat 8 yang memiliki resolusi rendah, untuk selanjutnya disarankan menggunakan citra dengan resolusi yang lebih tinggi. Kemudian penting juga untuk penambahan parameter analisis agar menghasilkan informasi spasial yang lebih baik.

\section{Daftar Pustaka}

Ajin, R., Loghin, A.-M., Vinod, P., \& Jacob, M. (2016). Forest Fire Risk Zone Mapping Using RS and GIS Techniques: A Study in Achankovil Forest Division, Kerala, India. Journal of Earth, Environment and Health Sciences, 2(3), 109-115.

Asterindah, F. S. (2017). Implementasi Kebijakan Pengendalian Kebakaran Hutan dan lahan Gambut di Ogan Komering Ilir. Jurnal Abdimas Mandiri, 7(2), 71-77.

BNPB. (2013). Indeks Rawan Bencana Indonesia. Jakarta: Badan Nasional Penanggulangan Bencana.

BPS Kabupaten Dumai. (2018). Dumai dalam Angka 2017.

Christiawan, P. I. (2018). Cultural Landscape : A Bridge Between Deforestation And Local Community? Journal of Landscape Ecology, 11(2), 77-87. https://doi.org/10.2478/jlecol-2018-0008

Cutter, S. L. (1996). Vulnerability to Environmental Hazards. In Progress in Human Geography.
Garbutta, K., Ellulb, C., \& Fujiyamab, T. (2015). Mapping Social Vulnerability to Flood Hazard in Norfolk, England. Environmental Hazards, 14(2), 156-186.

Hapsoro, A., \& Buchori, I. (2015). Kajian Kerentanan Sosial Dan Ekonomi Terhadap Bencana Banjir (Studi Kasus: Wilayah Pesisir Kota Pekalongan). Tekhnik Perencanaan Wilayah Dan Kota, 4(4), 542-553.

Jawad, A., Nurdjali, B., \& Widiastuti, T. (2015). Zonasi Daerah Rawan Kebakaran Hutan dan Lahan di Kabpaten Kubu Raya Provinsi Kalimantan Barat. Jurnal Hutan Lestari, 3(1), 88-97.

LPPM IPB. (2016). Peta dan Model Kerentanan Kebakaran Hutan dan Lahan Kabupaten Kapuas Provinsi Kalimantan Tengah. Bogor Agriculture Institute.

Mapilata, E., Gandasasmita, K., \& Djajakirana, G. (2013). Analisis Daerah Rawan Kebakaran Hutan dan Lahan Dalam Penataan Ruang di Kota Palangka Raya Provinsi Kalimantan Tengah. Globe, 15(2), 178-184.

Putra, A., Retnaningsih, A. T., \& Ikhwan, M. (2018). Pemetaan Daerah Rawan Kebakaran Hutan dan Lahan dengan Menggunakan Sistem Informasi Geografis (Studi Kasus: Kecamatan Bukit Batu, Kab Bengkalis). Jurnal Kehutanan, 13(1), 55-63.

Rahayu, Y., Mulud, K., \& Hijriani, A. (2016). Pemetaan Penyebaran Dan Prediksi Jumlah Penduduk Menggunakan Model Geometrik Di Wilayah Bandar Lampung Berbasis Web-GIS. Journal of Information Systems Engineering And Business Intelligence, 2(2), 95-101.

Ratnaningsih, A. T., \& Prastyaningsih, S. R. (2017). Dampak Kebakaran Hutan Gambut terhadap Subsidensi di Hutan Tanaman Industri. Jurnal Kehutanan, 12(1), 37-43.

Rauf, A. (2016). Dampak Kebakaran Lahan Perkebunan Kelapa Sawit di Lahan Gambut Kabupaten Aceh Barat Daya terhadap Sifat Tanah Gambut. Jurnal Pertanian Tropik, 3(3), 256-266.

Saputra, R., Sigit, S., \& Shandyavitri, T. (2017). Mitigasi Bencana Kebakaran Lahan Gambut berdasarkan Metode Network Analysis Berbasi GIS (Studi Kasus: Pulau Bengkalis). Jurnal FTEKNIK, 4(2), 1-11.

Tata, H. L., Narendra, B. H., \& Nawazin. (2017). Tingkat Kerawanan Kebakaran Gambut di Kabupaten Musi Banyuasin Sumatra Selatan. Jurnal Penelitian Hutan Tanaman, 14(1), 51-71. 
Aplikasi SIG untuk Pemetaan Bahaya Kebakaran Hutan dan Lahan di Kota Dumai/ Ria Viviyanti, Tamima Azri Adila, Riki Rahmad

Wesnawa, I. G. A., \& Christiawan, P. I. (2014). Geografi Bencana. Jakarta: Graha llmu.

Widodo, R. B. (2014). Permodelan Spasial Resiko Kebakaran Hutan (Studi Kasus Provinsi Jambi, Sumatera). Jurnal Pembangunan Wilayah Kota, 10(2), 128138. 